\title{
A CASE Study
}

\section{Green revolution- phytoremediation of heavy metals from industrial effluent by water hyacinth}

\author{
D. PAMILA, A. SIVALINGAM AND M. THIRUMARIMURUGAN
}

\begin{abstract}
Heavy metals $(\mathrm{Pb}, \mathrm{Hg}, \mathrm{As}, \mathrm{Cd}, \mathrm{Cr})$ present in many industrial effluents are non-biodegradable which affect the food chain and are hazardous to all living beings. Phytoremediation is a green revolution, innovative, economic, environmental friendly using metal accumulating plants to remove heavy metals. Water and plant factors such as physio-chemical characteristics, metal bioavailability, plant's ability to uptake, accumulate, translocate and detoxify metal amounts for phytoremediation efficiency. Eichhornia Crassipies, Limnobium Laevigatum are aquatic floating macrophytic plants occurring in meso and eutropic water reservoirs have natural ability of hyperaccumulator or by inducing chelating agents, phytoremediation can be achieved. The accumulation potential in aquatic plants is calculated by bioconcentration and translocation factor.
\end{abstract}

KEY WORDS : Heavy metal, Phytoremediation, Hyporaccumulatior, Eichhornia crassipies, Limnobium laevigatum

How to cite this Article : Pamila, D., Sivalingam, A. and Thirumarimurugan, M. (2016). Green revolution- phytoremediation of heavy metals from industrial effluent by water hyacinth. Engg. \& Tech. in India, 7 (1) : 56-64. 